\title{
The Evolution of Complex Carbide Precipitates in a Low Alloy Cr-Mo-V Steel after Long-Term Aging Treatment
}

\author{
Zili Liu ${ }^{1,2, *}$, Chunming Liu ${ }^{1, *}$, Lede Miao ${ }^{2}$, Xiaofei Guo ${ }^{3}$, Jianhua Ding ${ }^{2}$ and \\ Hanqian Zhang ${ }^{2}$ (1) \\ 1 School of Materials Science and Engineering, Northeastern University, Shenyang 110819, China \\ 2 Central Research Institute (R\&D Center), Baoshan Iron \& Steel Co. Ltd., Shanghai 201900, China; \\ miaolede@baosteel.com (L.M.); jhding@baosteel.com (J.D.); hq_zhang@baosteel.com (H.Z.) \\ 3 Steel Institute, RWTH Aachen University, 52072 Aachen, Germany; xiaofei.guo@iehk.rwth-aachen.de \\ * Correspondence: liu_2323@126.com (Z.L.); cmliu@mail.neu.edu.cn (C.L.); \\ Tel.: +86-21-26641024 (Z.L.); +86-24-83686627 (C.L.)
}

Received: 30 April 2019; Accepted: 24 May 2019; Published: 27 May 2019

check for updates

\begin{abstract}
Complex carbide precipitates in a quenched and tempered low alloy $\mathrm{Cr}-\mathrm{Mo}-\mathrm{V}$ steel after long-term aging at $650{ }^{\circ} \mathrm{C}$ for $13,000 \mathrm{~h}$ and $30,000 \mathrm{~h}$ were investigated in this study. The mass fraction and sizes of precipitates were quantified by electrolytical extraction technique. The types of precipitate were further studied by combined X-ray diffraction and transmission electron microscopy with selected area electron diffraction and energy dispersive spectrometry. A series of carbide precipitates, namely $\mathrm{MC}, \mathrm{M}_{7} \mathrm{C}_{3}, \mathrm{M}_{6} \mathrm{C}$, and $\mathrm{M}_{2} \mathrm{C}$, were found existing in the near-equilibrium state. The precipitate sequence of these carbides was identified as $M C+M_{7} C_{3}+M_{2} C \rightarrow M C+M_{2} C+M_{7} C_{3}$ $+\mathrm{M}_{6} \mathrm{C} \rightarrow \mathrm{MC}+\mathrm{M}_{7} \mathrm{C}_{3}+\mathrm{M}_{6} \mathrm{C}$. It was clarified that the stable phases for the investigated steel aged at $650{ }^{\circ} \mathrm{C}$ were composed of $\mathrm{MC}, \mathrm{M}_{7} \mathrm{C}_{3}$, and $\mathrm{M}_{6} \mathrm{C}$. For the first time, the in-situ transformations of $\mathrm{M}_{2} \mathrm{C}$ to $\mathrm{M}_{6} \mathrm{C}$ and $\mathrm{M}_{7} \mathrm{C}_{3}$ to $\mathrm{M}_{6} \mathrm{C}$ were directly observed. It was also observed that the nucleation site of the $\mathrm{M}_{6} \mathrm{C}$ was located at the interface of $\mathrm{M}_{7} \mathrm{C}_{3}$ carbides and the matrix. The orientation relationships between the secondary phases of the in-situ transforming carbides aged for 13,000 $\mathrm{h}$ and 30,000 $\mathrm{h}$ at $650{ }^{\circ} \mathrm{C}$ were established. The coherent interfaces between these secondary phases became incoherent with prolonged aging treatment due to the exerted strain field of the growing carbides.
\end{abstract}

Keywords: Cr-Mo-V steel; long-term aging; carbide evolution characterization; planar mismatch

\section{Introduction}

Low alloy Cr-Mo-V and Cr-Mo steels are creep resistant steels [1], showing excellent mechanical strength at high temperatures. They are extensively utilized in manufacturing key equipment in the power generation industry [2,3] and petroleum industry [4]. Different types of carbide precipitate manifested by aging treatment strengthen these low alloy steels; however, they also influence the microstructure stability [5] and high temperature creep resistant properties [6-9]. The characterization of carbide precipitates and their contribution to mechanical properties under different aging conditions have been intensively investigated [10-18]. Most of these aging treatments were carried out from several hours to several thousand hours at a temperature range between 300 and $750{ }^{\circ} \mathrm{C}$ [19-24]. Limited work focuses on long-term heat treatment with an aging time long enough to be regarded as approaching the equilibrium state [22]. However, the equilibrium states of the carbides are very important for understanding the degradation or the failure mechanism of the steel, since the material will be continuously exposed to high temperature during service. 
Much research work has been carried out to clarify the crystallographic orientation relationship between the precipitates and the ferrite matrix, as summarized in Table 1 [25-30]. The crystallographic orientation relationships between the in-situ transformed precipitates and the matrix are crucial for the in-depth understanding of carbide evolution and the mechanisms behind this evolution. Up to now, however, limited investigation has been performed on the orientation relationship between the in-situ transformed carbides in $\mathrm{Cr}-\mathrm{Mo}-\mathrm{V}$ steels [24]. Two nucleation mechanisms for the new carbide phases might work at the stage of aging; one is named 'in-situ transformation', which means the new carbide directly nucleates from the existing carbide and grows at the expense of the mother phase; another mechanism is called 'separate nucleation', which means the existing carbides are dissolved firstly in the base metal and then the new carbide nucleates and grows. Baker and Nutting postulated the in-situ transformation from $\mathrm{M}_{2} \mathrm{X}\left(\mathrm{M}_{2} \mathrm{C}\right)$ to $\mathrm{M}_{6} \mathrm{C}$ according to their indirect observations since 1959 [31]. The letter M represents the metallic component, such as $\mathrm{Fe}, \mathrm{V}, \mathrm{Cr}, \mathrm{Mo}, \mathrm{Mn}$, etc.; the letter $\mathrm{X}$ represents the non-metallic elements, such as $\mathrm{C}$ and $\mathrm{N}$. Beech has endeavored to find in-situ transformation by obtaining the electron diffraction patterns from individual precipitate but never succeeded [32]. Then Beech believed that carbide transformed by a mechanism of separate nucleation rather than an in-situ nucleation mechanism. There are several difficulties to get valuable crystallographic information of the in-situ transformed precipitates: first, sufficient aging treatment period to approach the equilibrium state; second, capturing the in-situ transformed complex carbide precipitates among the tens of thousands of precipitates in the aged specimen; third, the precise index of the complex selected area diffraction patterns from the in-situ transformed carbide precipitates.

Table 1. Orientation relationships between carbides and $\alpha$-Fe matrix.

\begin{tabular}{|c|c|c|}
\hline Carbide & Orientation Relationships with Matrix & Reference \\
\hline $\mathrm{M}_{3} \mathrm{C}$ & $(100)_{M_{3} C} / /(3 \overline{1} 1)_{\alpha-F e^{\prime}}(101)_{M_{3} C} / /(131)_{\alpha-F e^{\prime}}(001)_{M_{3} C} / /(\overline{21} 5)_{\alpha-F e}$ & [25] \\
\hline $\begin{array}{c}\mathrm{MC} \\
\left(\mathrm{M}_{4} \mathrm{C}_{3}\right)\end{array}$ & $\{100\}_{M_{4} C_{3}} / /\{100\}_{\alpha-F e},\langle 100\rangle_{M_{4} C_{3}} / /\langle 100\rangle_{\alpha-F e}$ & [26] \\
\hline $\mathrm{M}_{2} \mathrm{C}$ & $(0001)_{M_{2} C} / /(021)_{\alpha-F e^{\prime}}(11 \overline{2} 0)_{M_{2} C} / /(100)_{\alpha-F e^{\prime}}(\overline{1} 100)_{M_{2} C} / /(01 \overline{2})_{\alpha-F e}$ & \\
\hline $\mathrm{M}_{2} \mathrm{C}$ & $\begin{array}{l}(0001)_{M_{2} C} / /(011)_{\alpha-F e}(01 \overline{1} 1)_{M_{2} C} / /(110)_{\alpha-F e}(2 \overline{1} 10)_{M_{2} C} / /(1 \overline{1} 1)_{\alpha-F e} \\
(0001)_{M_{7} C_{3}} / /(011)_{\alpha-F e^{\prime}}(10 \overline{1} 0)_{M_{7} C_{3}} / /(11 \overline{1})_{\alpha-F e^{\prime}}(01 \overline{1} 0)_{M_{7} C_{3}} / /(\overline{2} 3 \overline{3})_{\alpha-F e}\end{array}$ & [28] \\
\hline $\mathrm{M}_{7} \mathrm{C}_{3}$ & $\begin{array}{c}(1 \overline{1} 00)_{M_{7} C_{3}} / /(100)_{\alpha-F e^{\prime}}(0001)_{M_{7} C_{3}} / /(21 \overline{1})_{\alpha-F e^{\prime}}(10 \overline{1} 0)_{M_{7} C_{3}} / /(102)_{\alpha-F e} \\
(01 \overline{1} 0)_{M_{7} C_{3}} / /(2 \overline{3} 1)_{\alpha-F e^{\prime}}(1 \overline{1} 00)_{M_{7} C_{3}} / /(011)_{\alpha-F e}\end{array}$ & [29] \\
\hline $\mathrm{M}_{6} \mathrm{C}$ & $(100)_{M_{6} C} / /(100)_{\alpha-F e}(011)_{M_{6} C} / /(011)_{\alpha-F e}(0 \overline{1} 1)_{M_{6} C} / /(0 \overline{1} 1)_{\alpha-F e}$ & [30] \\
\hline $\mathrm{M}_{23} \mathrm{C}_{6}$ & $(011)_{M_{23} C_{6}} / /(011)_{\alpha-F e}(\overline{1} 1 \overline{1})_{M_{23} C_{6}} / /(110)_{\alpha-F e}(\overline{211} 1)_{M_{23} C_{6}} / /(\overline{1} 10)_{\alpha-F e}$ & [30] \\
\hline
\end{tabular}

In previous studies [15,33], when similar steel was aged at about $650{ }^{\circ} \mathrm{C}$, there was usually a discrepancy between the experimental results and the theoretical calculations for the stable phases. Miyata and Sawaragi [34] used a thermodynamic database (THERMO-CALC) to calculate the equilibrium phases after a $650{ }^{\circ} \mathrm{C}$ aging treatment, which were supposed to be $\mathrm{M}_{23} \mathrm{C}_{6}+\mathrm{MC}$. Vyrostkova et al. [22] found different results in their calculations, which were supposed to be $\mathrm{M}_{6} \mathrm{C}+\mathrm{M}_{7} \mathrm{C}_{3}+\mathrm{MC}$. Therefore, the equilibrium phases at the aging temperature of $650{ }^{\circ} \mathrm{C}$ for the investigated steel are still an open issue from the scientific point of view, which still need to be clarified by experimental observation.

In our study, the selected area electron diffraction (SAED) patterns were indexed according to the crystallographic information of the typical carbides that may precipitate in the studied steel; these basic data are briefly described in Table 2 [35-38]. 
Table 2. Crystallographic information of typical carbides in low alloy $\mathrm{Cr}-\mathrm{Mo}-\mathrm{V}$ steel.

\begin{tabular}{ccccc}
\hline Carbide & Lattice Parameters $(\mathbf{n m})$ & Crystal System & Space Group & Reference \\
\hline $\mathrm{M}_{3} \mathrm{C}$ & $\mathrm{a}=0.4525$ & orthorhombic & Pnma & [35] \\
$\mathrm{b}$ & $=0.5087$ & & & \\
$\mathrm{M}_{6} \mathrm{C}$ & $\mathrm{c}=0.6743$ & cubic & $\mathrm{Fd} \overline{3} \mathrm{~mm}$ & {$[35]$} \\
$\mathrm{M}_{23} \mathrm{C}_{6}$ & $\mathrm{a}=1.1082$ & cubic & $\mathrm{Fm} \overline{3} \mathrm{~m}$ & {$[35]$} \\
$\mathrm{MC}$ & $\mathrm{a}=1.0621$ & cubic & $\mathrm{P} 4_{3} 32$ & {$[36]$} \\
$\mathrm{M}_{2} \mathrm{C}$ & $\mathrm{a}=0.8333$ & hexagonal & $\mathrm{P} 6_{3} / \mathrm{mmc}$ & {$[37]$} \\
& $\mathrm{a}=0.3002$ & & & \\
$\mathrm{M}_{7} \mathrm{C}_{3}$ & $\mathrm{c}=0.4724$ & Pnma & \\
& $\mathrm{a}=0.4526$ & & & \\
\hline
\end{tabular}

In the present study, quenched and tempered low alloy $\mathrm{Cr}-\mathrm{Mo}-\mathrm{V}$ steel was isothermally aged at $650^{\circ} \mathrm{C}$ for the period of $13,000 \mathrm{~h}$ and $30,000 \mathrm{~h}$, respectively. The type, precipitate sequence, nucleation mechanism, and crystal structure of the carbides, which precipitated during aging, were studied systematically by means of electrolytically extracted technique, $\mathrm{X}$-ray diffraction, and transmission electron microscopy. In particular, the evidences of an in-situ transformation of $\mathrm{M}_{2} \mathrm{C}$ to $\mathrm{M}_{6} \mathrm{C}, \mathrm{M}_{7} \mathrm{C}_{3}$ to $\mathrm{M}_{6} \mathrm{C}$ were directly observed for the first time. In addition, the orientation relationships between the in-situ transforming carbides were demonstrated by means of transmission electron microscopy (TEM) and the selected area electron diffraction (SAED) patterns and energy dispersive spectrometer (EDS). The interfaces between different phases in the complex precipitates were characterized accordingly. The current study will be very helpful to understand the complex precipitation phenomenon during long-term aging treatment of low alloy $\mathrm{Cr}-\mathrm{Mo}-\mathrm{V}$ steel.

\section{Experimental Procedure}

The Cr-Mo-V low alloy steel was melted in a vacuum furnace (Inductotherm, Rancocas, NJ, USA), cast into $150 \mathrm{~kg}$ blocks, hot rolled to plates of $50 \mathrm{~mm}$ thickness, austenitized at $950{ }^{\circ} \mathrm{C}$ for $4 \mathrm{~h}$, and water quenched. The quenched plates were tempered at $720^{\circ} \mathrm{C}$ for $150 \mathrm{~min}$ and air-cooled. Then the tempered steel plates were aged in a NCPE-411 type furnace (Nakanihon Ro Kogyo, Nagoya, Aichi-ken, Japan) at $650^{\circ} \mathrm{C}$ for $13,000 \mathrm{~h}$ and $30,000 \mathrm{~h}$, respectively. The chemical composition of the investigated steel is listed in Table 3.

Table 3. Chemical composition of the investigated low alloy $\mathrm{Cr}-\mathrm{Mo}-\mathrm{V}$ steel (in $\mathrm{wt} \%$ ).

\begin{tabular}{cccccccccc}
\hline $\mathbf{C}$ & $\mathbf{M n}$ & $\mathbf{P}$ & $\mathbf{S}$ & $\mathbf{C r}$ & $\mathbf{M o}$ & $\mathbf{N b}$ & $\mathbf{V}$ & $\mathbf{A l}$ & $\mathbf{N}$ \\
\hline 0.14 & 0.55 & 0.008 & 0.003 & 2.5 & 1.0 & 0.03 & 0.3 & 0.020 & 0.005 \\
\hline
\end{tabular}

Part of the base metal and the aged plates were machined to cylinder specimens with a diameter of $10 \mathrm{~mm}$ and a length of $70 \mathrm{~mm}$. They were subsequently dissolved in a $5 \mathrm{KCl}+1 \%$ citric acid distilled water solution to obtain the precipitates by electrolytic extraction technique. The extracted precipitates were filtered using a filter (Millipore, Darmstadt, Germany) with $0.05 \mu \mathrm{m}$ pores, thoroughly dried at $70^{\circ} \mathrm{C}$, and weighed by electronic balance (Mettler Toledo, Zurich, Switzerland) with the accuracy of $\pm 1 \mu \mathrm{g}$. The size distributions of the extracted precipitates were analyzed by a Marstersizer 2000 particle size analyzer from Malvern Instruments Company (Malvern, UK) with a measurement error of $\pm 3 \mathrm{~nm}$.

The extracted particle powder was analyzed by a Bruker D8 discover X-ray diffractometer (Bruker, Karlsruhe, Germany) with $\mathrm{CuK} \alpha$ radiation and graphite monochromators (Bruker, Karlsruhe, Germany). The extracted precipitates were analyzed on a piece of glass plate in the air atmosphere. The start angle, end angle, and step size $(2 \theta)$ were $10^{\circ}, 80^{\circ}$, and $0.02^{\circ}$, respectively, with a count time of $2.0 \mathrm{~s}$ per step. 
The specimens prepared for transmission electron microscopy (TEM, JEOL, Akishima, Tokyo, Japan) observation were cut from the aged plate, mechanically ground to $80-100 \mu \mathrm{m}$, and punched into disks with $3 \mathrm{~mm}$ in diameter. The disks were further electro-polished using a solution of $10 \%$ perchloric acid in ethanol. A JEM-2100F scanning transmission electron microscope (JEOL, Akishima, Tokyo, Japan) attached with an Oxford energy-dispersive X-ray spectrometer (EDS, Oxford Instruments, Oxford, UK) was used for microstructure observation and carbide identification. Selected area electron diffraction (SAED) was employed for identifying the crystallographic details of the complex precipitates.

\section{Results}

\subsection{Mass Fraction of Precipitates in Different Aging Conditions}

The mass fraction of the precipitates extracted from specimens was calculated by the following formula:

$$
\mathrm{f}=\frac{m_{p}}{m_{0}-m_{r}} \times 100 \%=\frac{m_{p}}{\Delta m} \times 100 \%
$$

where $m_{p}$ is the weight of the extracted precipitates of the aged specimen, $m_{0}$ is the original weight of the aged specimen before electrolytically extraction, and $m_{r}$ is the remained weight of the aged specimen after the extraction experiment.

Figure 1a displays the mass fraction of precipitates in the specimens aged at $650{ }^{\circ} \mathrm{C}$ for the applied aging time. The mass fraction of the precipitates increases steeply in the specimens aged at $13,000 \mathrm{~h}$ compared to that from the tempered specimen, which was designated as stage I. From the aging time of $13,000 \mathrm{~h}$ to $30,000 \mathrm{~h}$, which was defined as stage II, there was only a slight increase in the mass percentage of the precipitates.
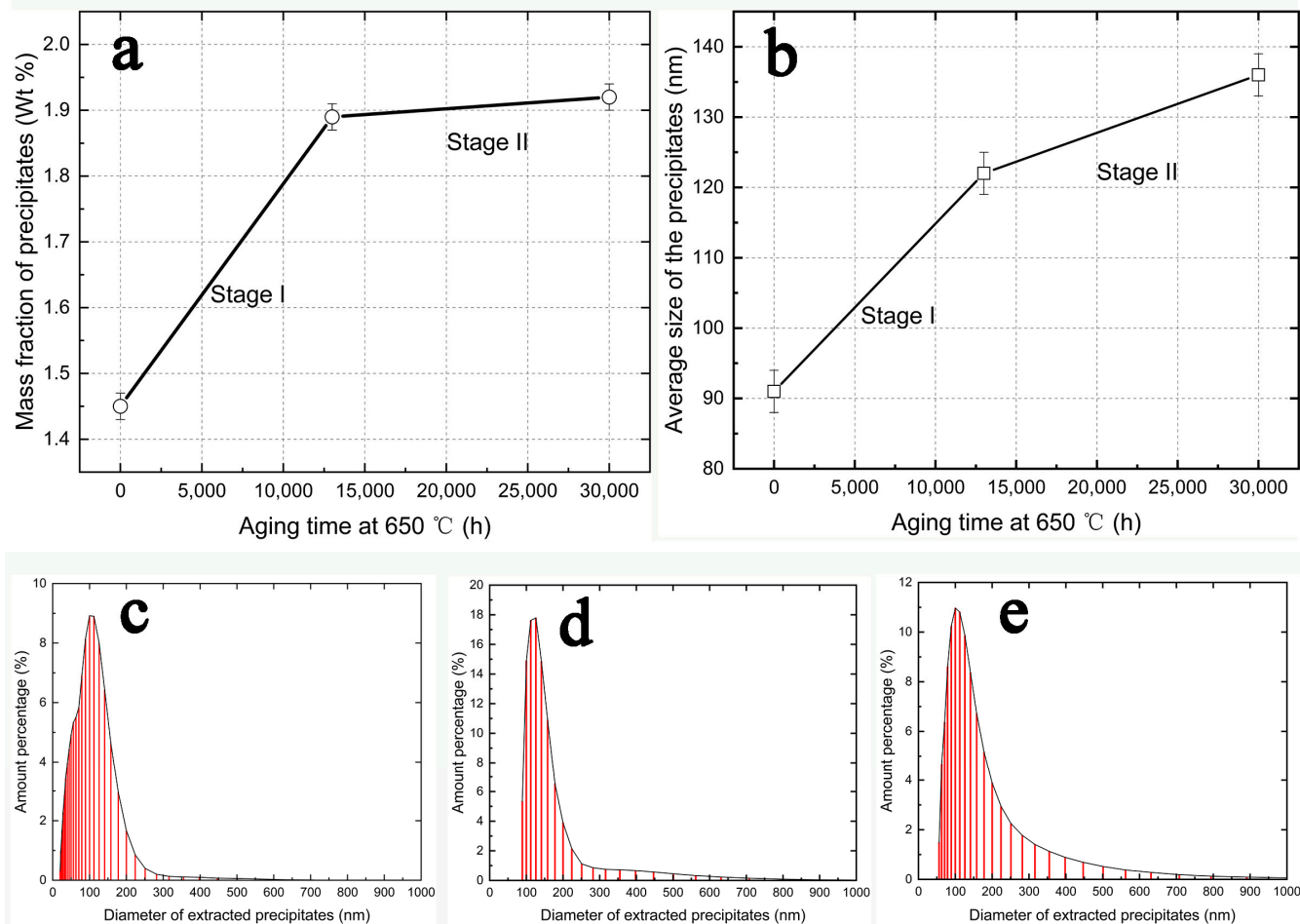

Figure 1. Mass fraction and size distribution of precipitates extracted from the specimens aged at $650{ }^{\circ} \mathrm{C}$ for different aging conditions. (a) Mass fraction of the precipitates at different aging conditions, (b) average size of the precipitates at different aging conditions, (c-e) size distribution of precipitates extracted from the quenched and tempered specimen, the $650^{\circ} \mathrm{C}$ for $13,000 \mathrm{~h}$ aged specimen, and the $650{ }^{\circ} \mathrm{C}$ for $30,000 \mathrm{~h}$ aged specimen. 


\subsection{Particle Size Distribution}

Figure $1 \mathrm{~b}$ shows that the average sizes of the extracted precipitates were $91 \mathrm{~nm}, 121 \mathrm{~nm}$, and $136 \mathrm{~nm}$ for the $0 \mathrm{~h}, 13,000 \mathrm{~h}$, and 30,000 h aging treated specimens, respectively. Comparing the average particle size increment of the two stages, the increment of stage II was much smaller than stage I, although the aging time of stage IIwas longer than stage I. The size distribution of the extracted precipitates was plotted, as shown in Figure 1c-e. Some ultra-fine precipitates may have been lost during the filtering process.

\subsection{X-ray Diffraction Analysis of the Extracted Precipitates}

X-ray diffraction analysis was performed to identify the types and mass fraction of the precipitates from the electrolytic extracted particles. Figure 2 reveals the diffraction patterns of the extracted precipitates corresponding to specimens aged at $650{ }^{\circ} \mathrm{C}$ for $0,13,000$, and $30,000 \mathrm{~h}$, respectively. No obvious diffracted peaks were found at the angle below 30 degrees. Table 4 summarizes the detected types of precipitates from the diffraction pattern. The precipitates extracted from the quenched and tempered specimens consisted of $\mathrm{M}_{7} \mathrm{C}_{3}, \mathrm{M}_{2} \mathrm{C}$, and $\mathrm{MC}$. After aging treatment at $650{ }^{\circ} \mathrm{C}$ for $13,000 \mathrm{~h}$, the diffraction peaks from $\mathrm{M}_{7} \mathrm{C}_{3}$ became weaker and new diffraction peaks corresponding to the lattice structure of $\mathrm{M}_{6} \mathrm{C}$ appeared. The diffraction peaks from the 30,000 $\mathrm{h}$ aged specimens had identical peak angles as the 13,000 $\mathrm{h}$ aged specimen. The only difference was that the $30,000 \mathrm{~h}$ aged specimen had a stronger peak intensity.

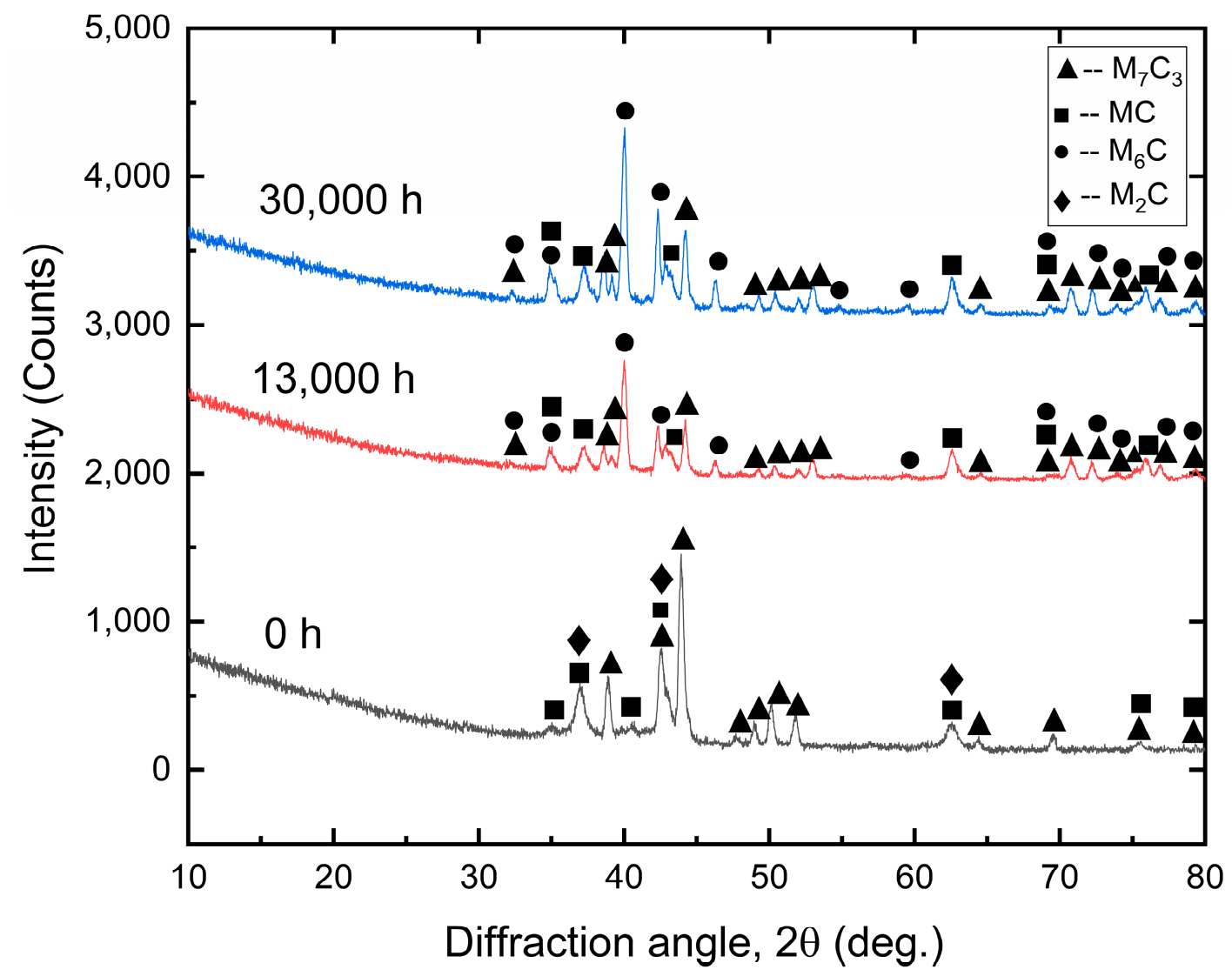

Figure 2. X-ray diffraction patterns of the electrolytic extracted precipitates from different aging conditions. 
Table 4. The types of the precipitates from the $650{ }^{\circ} \mathrm{C}$ aged specimens as identified by X-ray diffraction measurements.

\begin{tabular}{ccc}
\hline Aging Temperature $\left({ }^{\circ} \mathbf{C}\right)$ & Aging Time (h) & Types of Carbides \\
\hline 650 & 0 & $\mathrm{M}_{7} \mathrm{C}_{3}+\mathrm{MC}+\mathrm{M}_{2} \mathrm{C}$ \\
650 & 13,000 & $\mathrm{M}_{7} \mathrm{C}_{3}+\mathrm{MC}+\mathrm{M}_{6} \mathrm{C}$ \\
650 & 30,000 & $\mathrm{M}_{7} \mathrm{C}_{3}+\mathrm{MC}+\mathrm{M}_{6} \mathrm{C}$ \\
\hline
\end{tabular}

The changes of the intensity of the diffraction peaks, to some extent, was a reflection of the change of the mass fraction of each type of precipitate. Figure 3 shows the calculated mass fraction of each type of precipitate by applying the Rietveld full-pattern fitting algorithm method [39]. The TOtal PAttern Solution (TOPAS, version 4.1) developed by Bruker company (Karlsruhe, Germany) was used for the refinement, and weighted pattern R-factor (Rwp) was selected as a criterion to judge the refinement. In the current experiment, the Rwp value was about $8 \%$, which was below the value of $10 \%$ for reliable refinement. The amount of $\mathrm{M}_{7} \mathrm{C}_{3}$ type of carbide decreased, whilst the amounts of the $\mathrm{MC}$ and $\mathrm{M}_{6} \mathrm{C}$ carbides increased with prolonged aging time. $\mathrm{M}_{2} \mathrm{C}$ disappeared when aging time was longer than $13,000 \mathrm{~h}$.

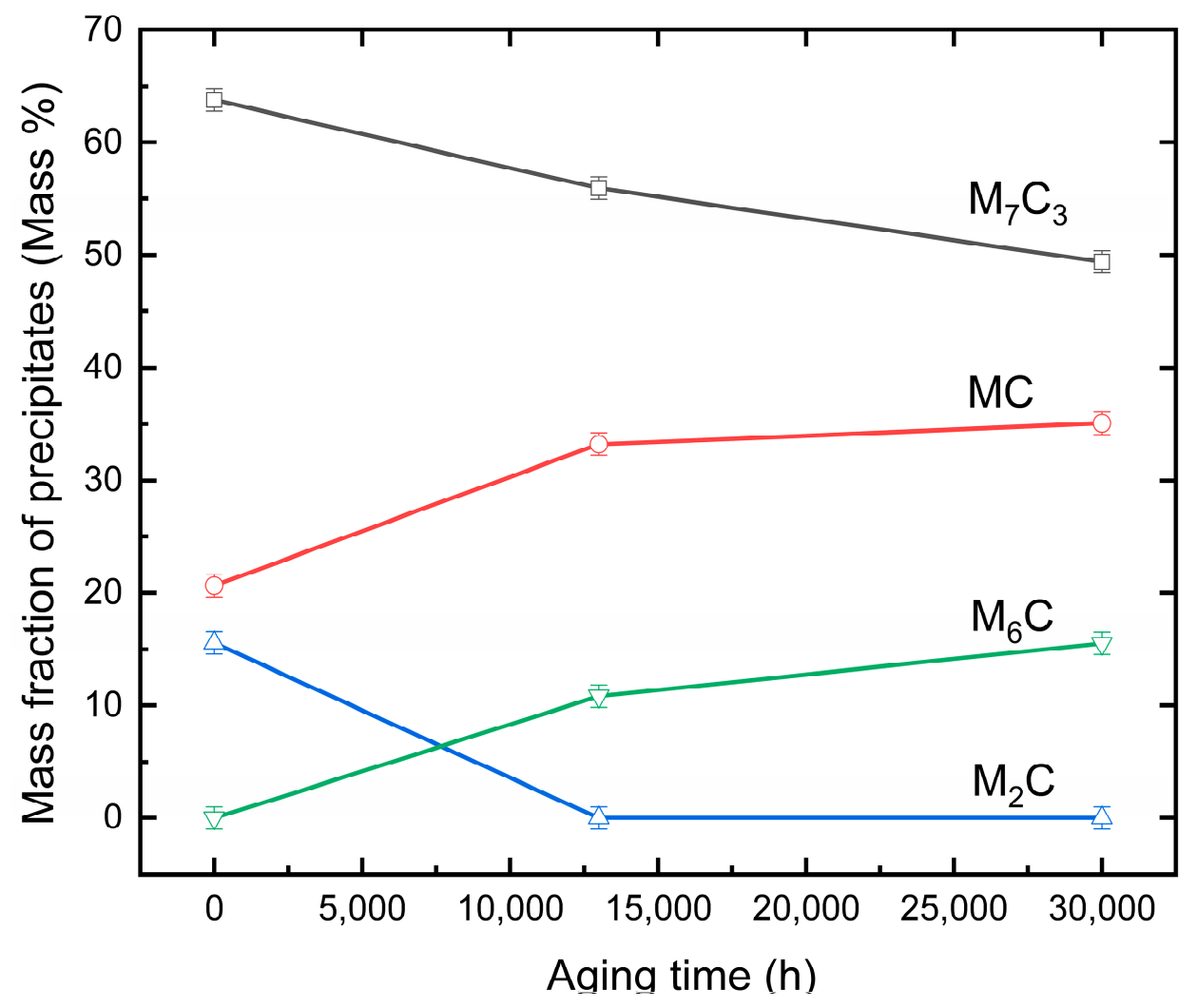

Figure 3. Mass fraction of different types of precipitates with prolonged aging.

3.4. TEM, SAED, and EDS Characterization of the Crystallographic Orientation Relationship of the In-Situ Transformed Carbides

Figure 4 reveals the transformation from existing $\mathrm{M}_{7} \mathrm{C}_{3}$ to $\mathrm{M}_{6} \mathrm{C}$ in the specimen aged at $650{ }^{\circ} \mathrm{C}$ for 13,000 $\mathrm{h}$ by combined TEM, SAED, and EDS characterization. Figure $4 \mathrm{a}, \mathrm{b}$ display the BF (Bright-Field) and DF (Dark-Field) TEM images of the $\mathrm{M}_{7} \mathrm{C}_{3}+\mathrm{M}_{6} \mathrm{C}$ complex precipitate. The spot used for the conventional dark field image was $(\overline{4} 2 \overline{2})_{M_{6} C}$. The SAED patterns, as seen in Figure $4 c$, revealed that the diffracted spots of different phases tangled together in the same image, which was completely different from the ordered pattern of a single phase. Figure $4 \mathrm{~d}$ shows the indexing of the diffraction spots of the SAED patterns in Figure $4 \mathrm{c}$. It indicates that the transformation of $\mathrm{M}_{7} \mathrm{C}_{3}$ to $\mathrm{M}_{6} \mathrm{C}$ took place 
according to an in-situ mechanism. The crystallographic orientation relationships between the $\mathrm{M}_{7} \mathrm{C}_{3}$ and $\mathrm{M}_{6} \mathrm{C}$ obtained from the SAED pattern (Figure $4 \mathrm{~d}$ ) were identified as follows:

$$
\begin{aligned}
& (41 \overline{51})_{M_{7} C_{3}} / /(\overline{4} 2 \overline{2})_{M_{6} C} \\
& {[\overline{1} 2 \overline{1} 3]_{M_{7} C_{3}} / /[011]_{M_{6} C}}
\end{aligned}
$$
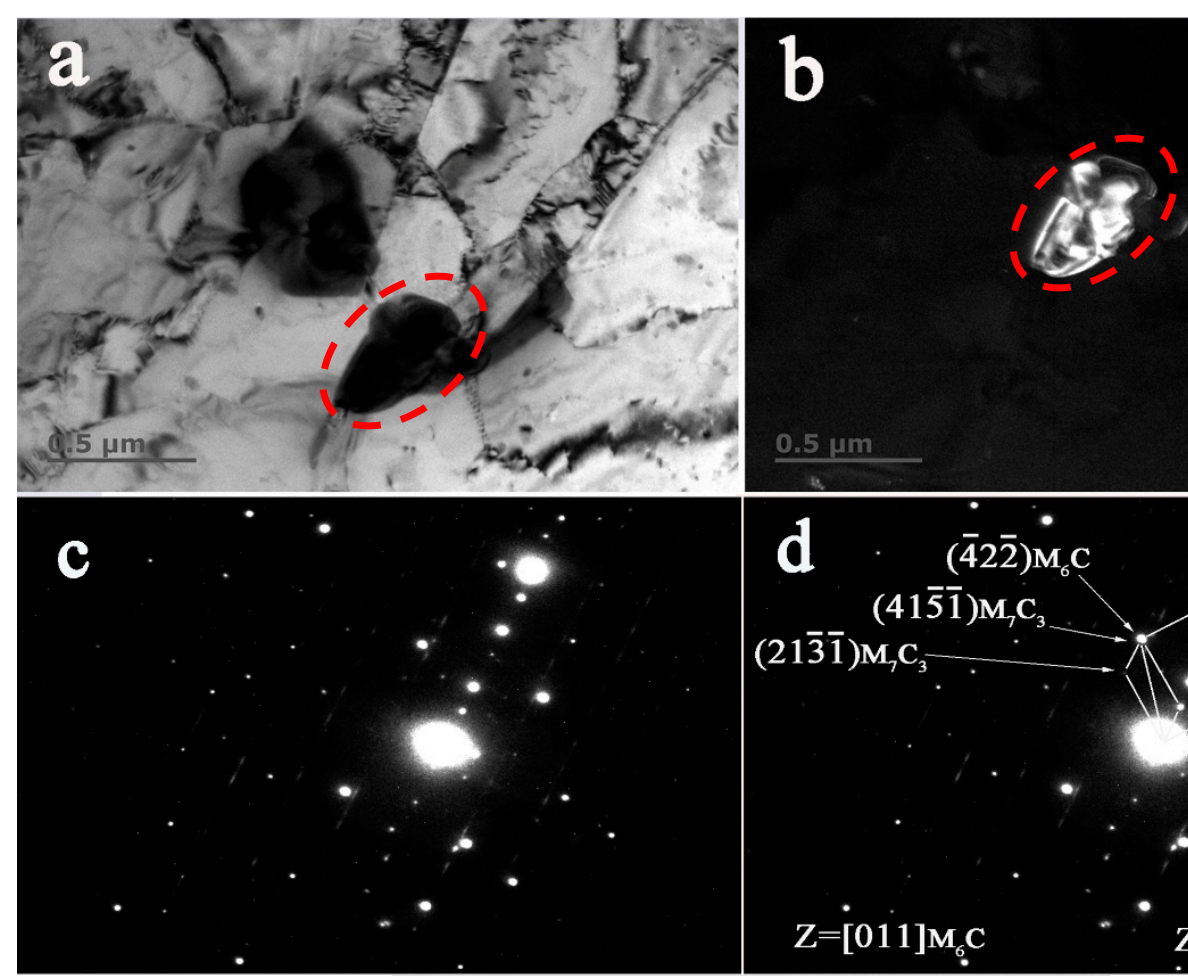

$0.5 \mu \mathrm{m}$
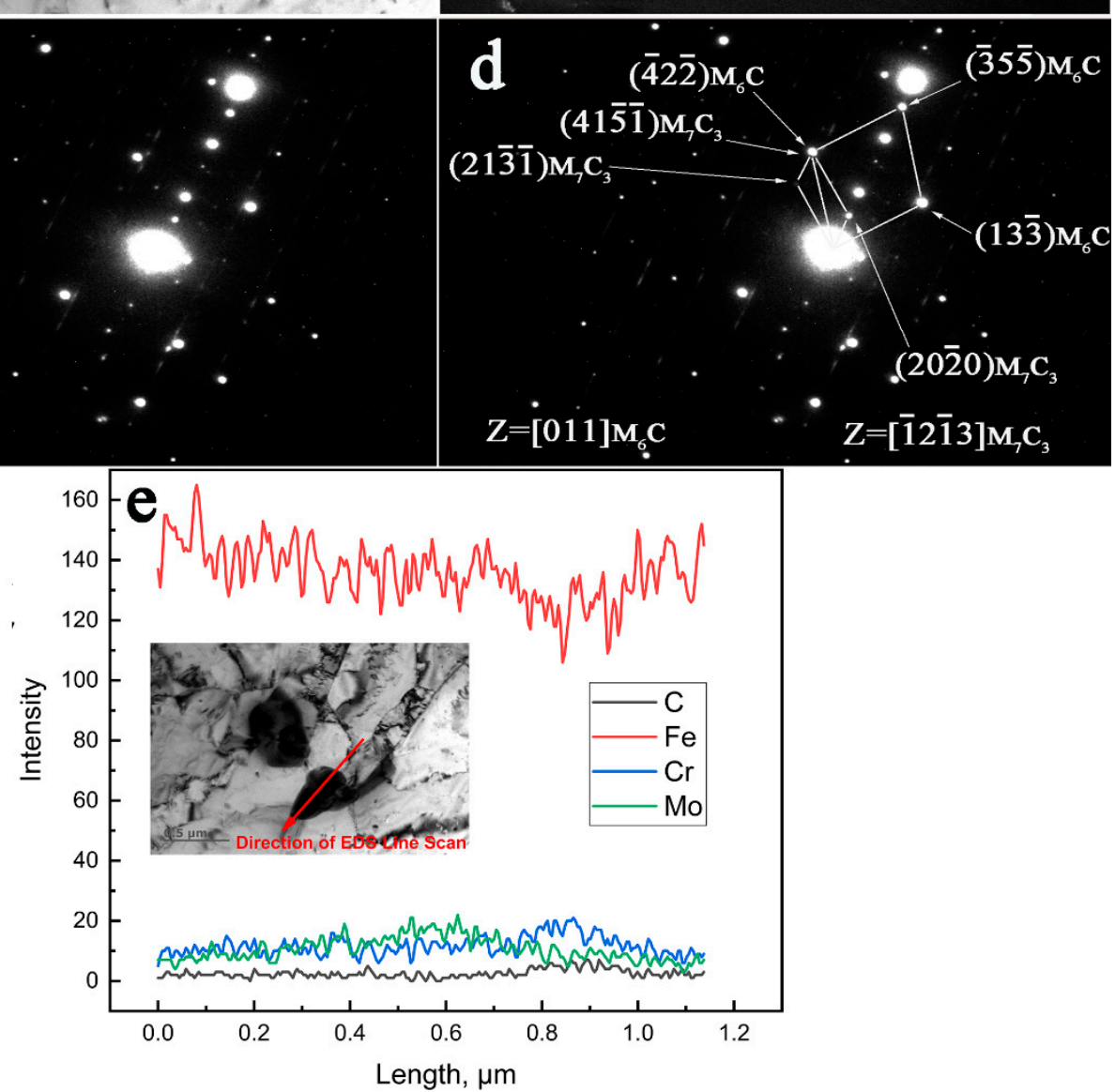

Figure 4. TEM characterization of the in-situ transformation of $\mathrm{M}_{7} \mathrm{C}_{3}$ to $\mathrm{M}_{6} \mathrm{C}$ in the low alloy $\mathrm{Cr}-\mathrm{Mo}-\mathrm{V}$ steel aged at $650{ }^{\circ} \mathrm{C}$ for $13,000 \mathrm{~h}$. (a) BF image, (b) DF image, (c) the original selected area electron diffraction (SAED) pattern, (d) the corresponding indexed SAED pattern, (e) the energy dispersive spectrometer (EDS) line scan.

Figure $4 \mathrm{e}$ shows the distribution of the main elements in the complex precipitates along the direction of the arrow in the inserted picture in Figure 4e. It reveals that the precipitate definitely consisted of two different particles; one was rich in $\mathrm{Mo}\left(\mathrm{M}_{6} \mathrm{C}\right)$ and the other was rich in $\mathrm{Cr}\left(\mathrm{M}_{7} \mathrm{C}_{3}\right)$. 
Figure 5 reveals an example of the transformation from existing $\mathrm{M}_{2} \mathrm{C}$ to $\mathrm{M}_{6} \mathrm{C}$ in the specimen aged at $650{ }^{\circ} \mathrm{C}$ for $13,000 \mathrm{~h}$ by combined TEM, SAED, and EDS characterization. The BF and DF images from Figure $5 \mathrm{a}, \mathrm{b}$ reveal the comparable size of the precipitates described in Figure 4 . The spot used for the dark field image in Figure $5 \mathrm{~b}$ was $(133)_{M_{6} C}$. The orientation relationships between $\mathrm{M}_{2} \mathrm{C}$ and $\mathrm{M}_{6} \mathrm{C}$ as indexed in Figure $5 \mathrm{~d}$ are presented as follows:

$$
\begin{aligned}
& (02 \overline{2} 1)_{M_{2} C} / /(266)_{M_{6} C} \\
& {[11 \overline{26}]_{M_{2} C} / /[31 \overline{2}]_{M_{6} C}}
\end{aligned}
$$
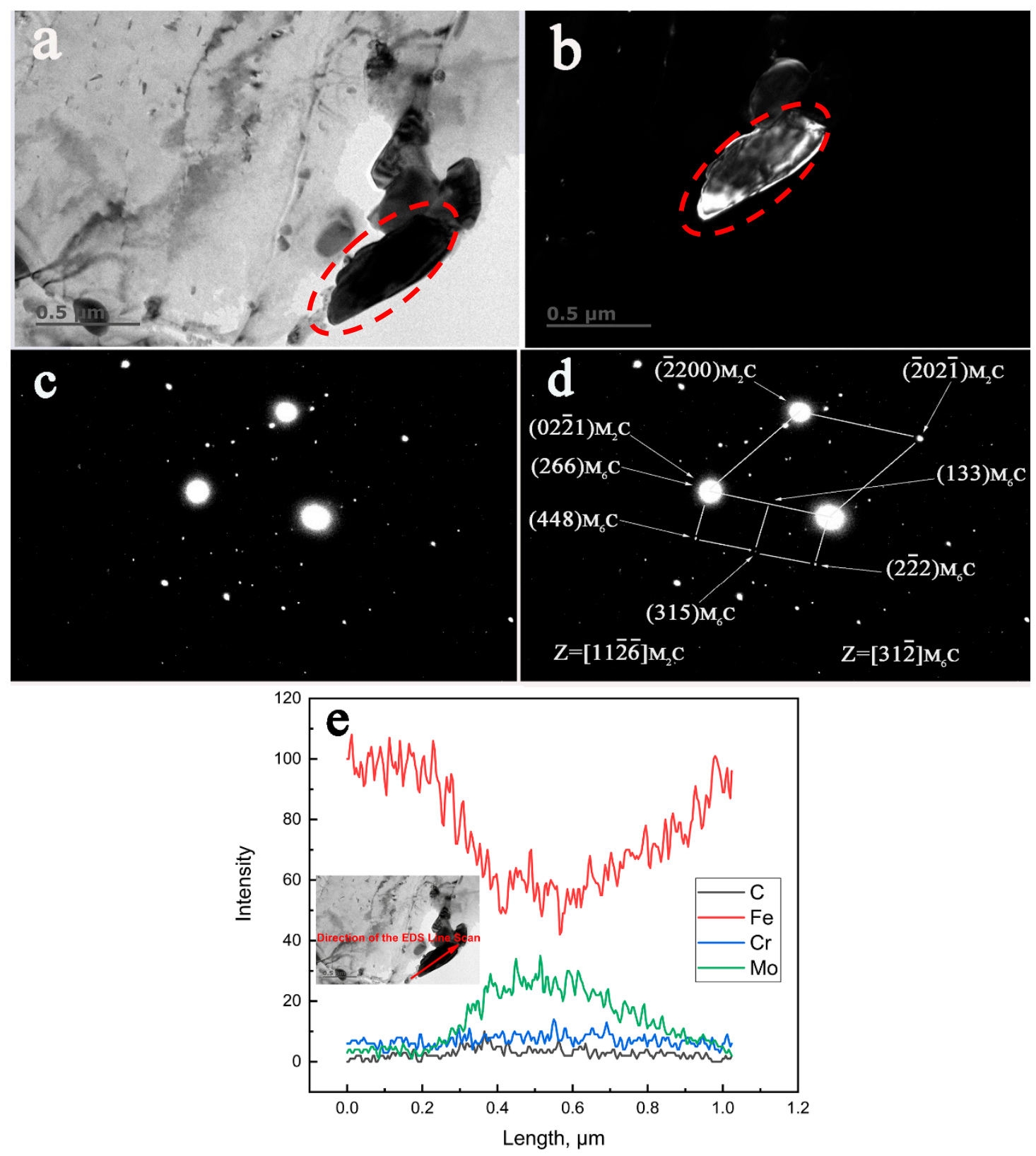

Figure 5. TEM characterization of the in-situ transformation of $\mathrm{M}_{2} \mathrm{C}$ to $\mathrm{M}_{6} \mathrm{C}$ in the low alloy $\mathrm{Cr}-\mathrm{Mo}-\mathrm{V}$ steel aged at $650{ }^{\circ} \mathrm{C}$ for $13,000 \mathrm{~h}$. (a) BF image, (b) DF image, (c) the original SAED pattern, (d) the corresponding indexed SAED pattern, (e) the EDS line scan.

Figure $5 c$ is the original SAED pattern of the studied precipitate. As shown in Figure $5 \mathrm{e}$, it is clear that this carbide was rich in Mo and poor in $\mathrm{Cr}$. 
The in-situ transformation from $M_{7} C_{3}$ to $M_{6} C$ and from $M_{2} C$ to $M_{6} C$ was also observed in the specimen aged at $650{ }^{\circ} \mathrm{C}$ for $30,000 \mathrm{~h}$. The spot used for Figure $6 \mathrm{~b}$ was $(1 \overline{1} 1)_{M_{6} \mathrm{C}}$. As seen Figure $6 \mathrm{~d}$, the reflection spots that were diffracted from $\mathrm{M}_{7} \mathrm{C}_{3}$ and $\mathrm{M}_{6} \mathrm{C}$ could be seen in the same SAED pattern. Based on these indexed diffraction patterns, the crystallographic relationship between $M_{7} C_{3}$ and $M_{6} C$ could be determined as follows:

$$
[\overline{6} 515]_{M_{7} C_{3}} / /[011]_{M_{6} C}
$$
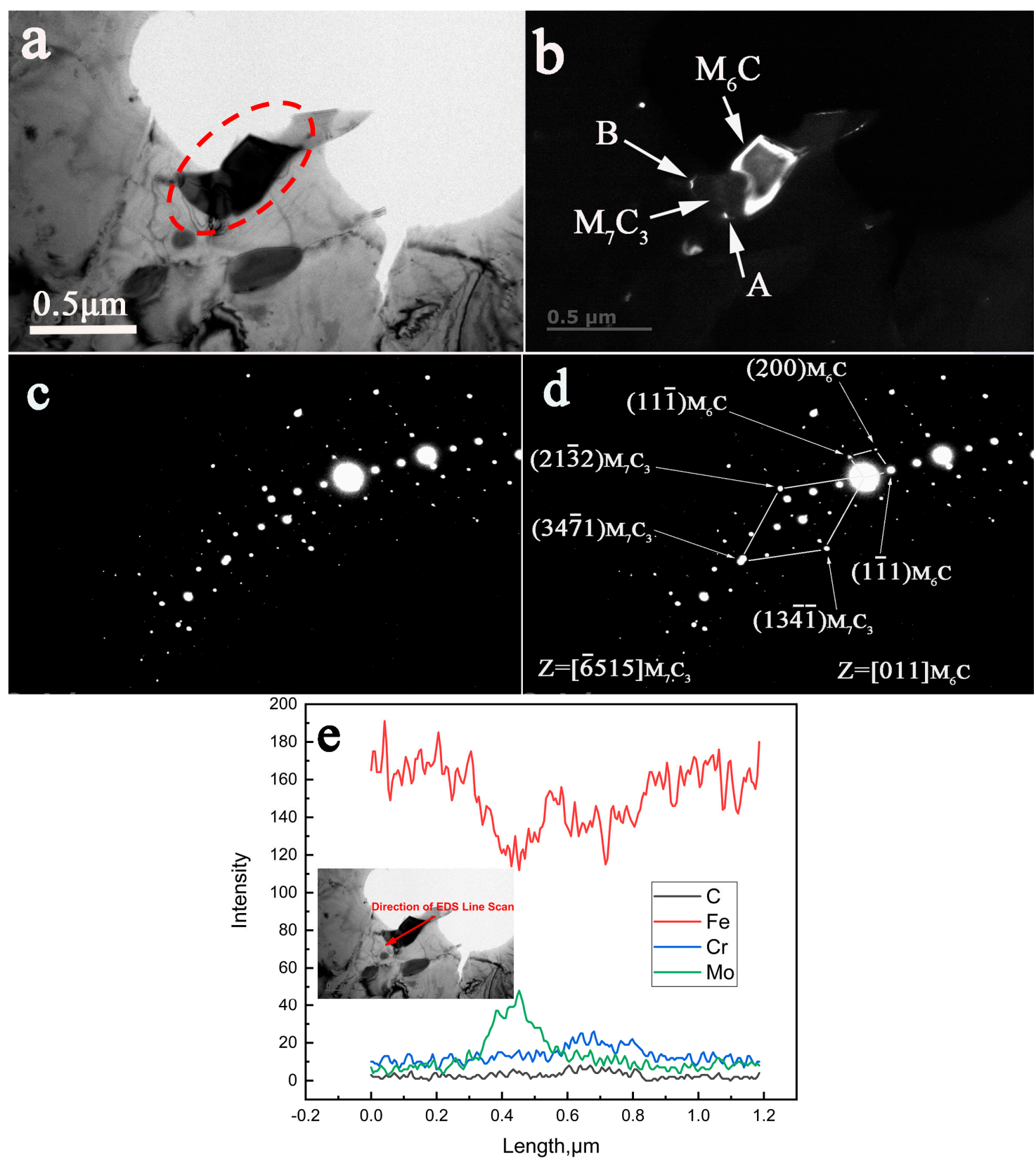

Figure 6. TEM characterization of the in-situ transformation of $\mathrm{M}_{7} \mathrm{C}_{3}$ to $\mathrm{M}_{6} \mathrm{C}$ in the low alloy $\mathrm{Cr}-\mathrm{Mo}-\mathrm{V}$ steel aged at $650{ }^{\circ} \mathrm{C}$ for $30,000 \mathrm{~h}$. (a) BF image, (b) DF image, A and B represent the small white precipitates near $\mathrm{M}_{7} \mathrm{C}_{3}$, (c) the original SAED pattern, (d) the corresponding indexed SAED pattern, (e) the EDS line scan. 
Similarly, a characterization of the in-situ transformed $\mathrm{M}_{2} \mathrm{C}$ and $\mathrm{M}_{6} \mathrm{C}$ in the $650{ }^{\circ} \mathrm{C}$ for $30,000 \mathrm{~h}$ aged specimen is shown in Figure 7. The spot used in Figure $7 \mathrm{~b}$ was $(40 \overline{4})_{M_{6} \mathrm{C}}$. The crystallographic relationship identified from the indexed SAED pattern from Figure $7 \mathrm{~d}$ were determined as follows:

$$
[\overline{1} 2 \overline{1} 0]_{M_{2} C} / /[5 \overline{6} 5]_{M_{6} C} \cdot
$$

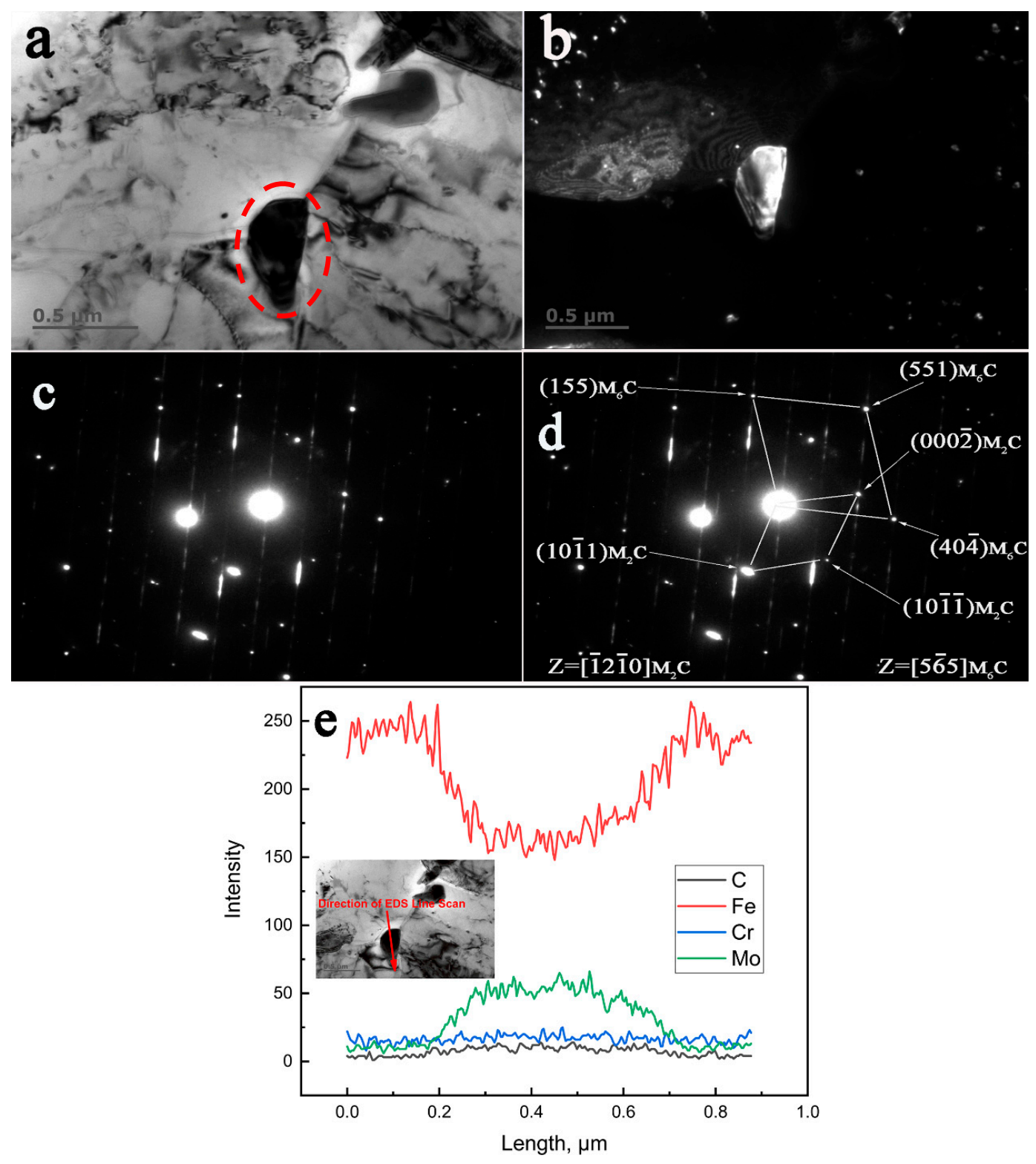

Figure 7. TEM characterization of the in-situ transformation of $\mathrm{M}_{2} \mathrm{C}$ to $\mathrm{M}_{6} \mathrm{C}$ in the low alloy $\mathrm{Cr}-\mathrm{Mo}-\mathrm{V}$ steel aged at $650{ }^{\circ} \mathrm{C}$ for $30,000 \mathrm{~h}$. (a) BF image, (b) DF image, (c) the original SAED pattern, (d) the corresponding indexed SAED pattern, (e) the EDS line scan.

The corresponding original SAED pattern is shown in Figures $6 c$ and $7 c$, respectively. The distribution of $\mathrm{Fe}, \mathrm{Cr}$, Mo, and $\mathrm{C}$ in the carbide particles that precipitated when the steel was aged at $650^{\circ} \mathrm{C}$ for $30,000 \mathrm{~h}$ can be easily seen in Figures 6e and $7 \mathrm{e}$.

According to the TEM and SAED analysis results, the crystallographic relationships of in-situ transformed complex precipitates in the investigated steel aged at $650{ }^{\circ} \mathrm{C}$ are summarized in Table 5 . Crystallographic relationships between the in-situ transformed precipitates in the investigated low 
alloy $\mathrm{Cr}-\mathrm{Mo}-\mathrm{V}$ steel aged at $650{ }^{\circ} \mathrm{C}$ for the different periods. It should be pointed out that these crystallographic relationships were identified in the present study but this does not mean that all in-situ transformed carbides will transform in the same way, as there might be some other crystallographic relationships between the in-situ transformed precipitates due to the complicated and changeable environment during carbides transformation.

Table 5. Crystallographic relationships between the in-situ transformed precipitates in the investigated low alloy $\mathrm{Cr}-\mathrm{Mo}-\mathrm{V}$ steel aged at $650{ }^{\circ} \mathrm{C}$ for the different periods.

\begin{tabular}{ccc}
\hline Aging Time (h) & In-Situ Transformation & $\begin{array}{c}\text { Crystallographic Relationships } \\
\text { between the Precipitates }\end{array}$ \\
\hline \multirow{2}{*}{13,000} & $\mathrm{M}_{7} \mathrm{C}_{3} \rightarrow \mathrm{M}_{6} \mathrm{C}$ & $(41 \overline{5} \overline{1})_{M_{7} \mathrm{C}_{3}} / /(\overline{4} 2 \overline{2})_{M_{6} \mathrm{C}}$ \\
& {$[\overline{1} 2 \overline{3}]_{M_{7} C_{3}} / /[011]_{M_{6} \mathrm{C}}$} \\
& $(02 \overline{1} 1)_{M_{2} \mathrm{C}} / /(266)_{M_{6} \mathrm{C}}$ \\
$\mathrm{M}_{2} \mathrm{C} \rightarrow \mathrm{M}_{6} \mathrm{C}$ & {$[11 \overline{26}]_{M_{2} \mathrm{C}} / /[31 \overline{2}]_{M_{6} \mathrm{C}}$} \\
$\mathrm{M}_{7} \mathrm{C}_{3} \rightarrow \mathrm{M}_{6} \mathrm{C}$ & {$[\overline{6} 515]_{M_{7} \mathrm{C}_{3}} / /[011]_{M_{6} \mathrm{C}}$} \\
$\mathrm{M}_{2} \mathrm{C} \rightarrow \mathrm{M}_{6} \mathrm{C}$ & {$[\overline{1} 2 \overline{1} 0]_{M_{2} \mathrm{C}} / /[5 \overline{6} 5]_{M_{6} \mathrm{C}}$} \\
\hline
\end{tabular}

Interestingly, the crystallographic relationships of the in-situ transforming precipitates between the specimen aged for 13,000 $\mathrm{h}$ and the specimen aged for 30,000 $\mathrm{h}$ were different. Coincident crystallographic planes of the in-situ transforming precipitates were not observed when the specimen was aged for 30,000 h. Overlapped crystal planes, however, were observed in the specimen aged for $13,000 \mathrm{~h}$.

The evidence of the in-situ transformation from $\mathrm{M}_{23} \mathrm{C}_{6}$ to $\mathrm{M}_{6} \mathrm{C}$ was not observed in this work. According to the experimental and thermodynamically calculated results of a similar low alloy $\mathrm{Cr}-\mathrm{Mo}-\mathrm{V}$ steel by Vyrostkova et al. [22,40], the $\mathrm{M}_{23} \mathrm{C}_{6}$ carbides prefer precipitating in larger quantity at the temperature below $600{ }^{\circ} \mathrm{C}$. This should be the reason that the $\mathrm{M}_{23} \mathrm{C}_{6}$ carbides were not observed in this work.

\section{Discussion}

\subsection{The Identification of Complex Carbide Precipitates in Long-Term Aged Cr-Mo-V Steel}

In this study, three types of precipitates, namely $M C, M_{7} C_{3}$, and $M_{6} C$, were identified in the $650{ }^{\circ} \mathrm{C} 13,000 \mathrm{~h}$ and $30,000 \mathrm{~h}$ aged specimens by means of $\mathrm{X}$-ray diffraction. The calculation of the mass fractions of the respective precipitates by Reitveld full-pattern fitting algorithm method and TOPAS indicated the reduction of $\mathrm{M}_{7} \mathrm{C}_{3}$ and $\mathrm{M}_{2} \mathrm{C}$ precipitates with prolonged aging time at $650{ }^{\circ} \mathrm{C}$, while the mass fractions of $M C$ and $M_{6} C$ precipitates increased. It indicated the transition of the $M_{7} C_{3}$ and $M_{2} C$ precipitates into $\mathrm{MC}$ or $\mathrm{M}_{6} \mathrm{C}$ during aging.

The SAED investigation gave additional information about the complex precipitates, which were identified as $M_{7} C_{3}+M_{6} C$ and $M_{2} C+M_{6} C$ in the 13,000 $h$ and 30,000 h aged specimens, respectively. It was confirmed by both analysis methods that the types of precipitates in the $650{ }^{\circ} \mathrm{C}$ long-term aged $\mathrm{Cr}-\mathrm{Mo}-\mathrm{V}$ steel consisted of $\mathrm{MC}, \mathrm{M}_{7} \mathrm{C}_{3}, \mathrm{M}_{6} \mathrm{C}$, and $\mathrm{M}_{2} \mathrm{C}$. The present work detected the $\mathrm{M}_{2} \mathrm{C}$, $\left(\mathrm{M}_{2} \mathrm{C}+\mathrm{M}_{6} \mathrm{C}\right)$ for the first time, which has not been reported in previous research on similar materials [22]. Since $\mathrm{M}_{2} \mathrm{C}$ is a minority phase in this investigation, it could not be observed by $\mathrm{X}$-ray diffraction due to the relatively low sensitivity of this technique [2]. Moreover, the size of the MC precipitate was too small to obtain its electron diffraction pattern under SAED investigation. The application of multiple inspection techniques is necessary for identifying the complex carbide precipitates in low alloy $\mathrm{Cr}-\mathrm{Mo}-\mathrm{V}$ steel.

The $\mathrm{M}_{6} \mathrm{C}$ precipitates were clearly detected by both X-ray diffraction and TEM methods in the long-term aged specimens in this work. When the aging treatment was not approaching the equilibrium 
state, such as aging between $450{ }^{\circ} \mathrm{C}$ and $650^{\circ} \mathrm{C}$ from several to one thousand hours $[19,23,41]$, the equilibrium phase of $\mathrm{M}_{6} \mathrm{C}$ could not be observed. The experimental evidences in the present investigation indicate that the $\mathrm{M}_{7} \mathrm{C}_{3}$ is the predominant carbide under the applied aging condition. This result is consistent with the theory that a relatively high $\mathrm{Cr}$ and $\mathrm{Mn}$ content in steel can accelerate the precipitation of $\mathrm{M}_{7} \mathrm{C}_{3}$ carbides $[23,33]$.

\subsection{The Sequence of Carbide Precipitation}

As a very important topic of the precipitate phenomenon, the sequence of carbide precipitation has been intensively investigated. Baker and Nutting carried out pioneering work and studied the precipitation sequences during tempering of $2.25 \mathrm{Cr}-1 \mathrm{Mo}$ steel [31]; they clarified the precipitation sequence as:

$$
\begin{aligned}
& \mathcal{E} \text {-carbide } \rightarrow \text { cementite } \rightarrow\left(\text { cementite }+\mathrm{M}_{2} \mathrm{C}\right) \rightarrow \mathrm{M}_{23} \mathrm{C}_{6} \rightarrow \mathrm{M}_{6} \mathrm{C} ; \\
& \mathcal{\varepsilon} \text {-carbide } \rightarrow \text { cementite } \rightarrow\left(\text { cementite }+\mathrm{M}_{2} \mathrm{C}\right) \rightarrow \mathrm{Cr}_{7} \mathrm{C}_{3} \rightarrow \mathrm{M}_{6} \mathrm{C} .
\end{aligned}
$$

Andrews, Hughes, and Dyson [42] studied the precipitation sequence at $700{ }^{\circ} \mathrm{C}$ in $\mathrm{Cr}-\mathrm{Mo}-\mathrm{V}$ rotor steels, which were summarized as follows:

$$
\begin{gathered}
\text { Matrix } \rightarrow \mathrm{M}_{3} \mathrm{C} \rightarrow \mathrm{M}_{6} \mathrm{C} ; \\
\text { Matrix } \rightarrow \mathrm{M}_{2} \mathrm{C} \rightarrow\left(\mathrm{M}_{2} \mathrm{C}+\mathrm{M}_{6} \mathrm{C}\right) \rightarrow \mathrm{M}_{6} \mathrm{C} .
\end{gathered}
$$

The precipitate sequence can be influenced by many factors, such as chemical composition $[17,20,22,23]$, original microstructure $[10,16,18]$, aging temperature $[12,13,23,31]$, and stress state of the steels [7]. Most research work focuses on relatively short-term aging without achieving the equilibrium state $[15,22]$, which do not completely reveal the precipitate sequence at a given aging temperature. We applied the aging temperature of $650{ }^{\circ} \mathrm{C}$ and the aging time up to $30,000 \mathrm{~h}$ and approached the equilibrium state. We found the precipitation sequence for the aged Cr-Mo-V low alloy steel as follows:

$$
\mathrm{MC}+\mathrm{M}_{7} \mathrm{C}_{3}+\mathrm{M}_{2} \mathrm{C} \rightarrow \mathrm{MC}+\mathrm{M}_{2} \mathrm{C}+\mathrm{M}_{7} \mathrm{C}_{3}+\mathrm{M}_{6} \mathrm{C} .
$$

Baker and Nutting, in 1959, speculated that $\mathrm{M}_{6} \mathrm{C}$ may form at the expense of $\mathrm{Mo}_{2} \mathrm{C}, \mathrm{M}_{23} \mathrm{C}_{6}$, or $\mathrm{Cr}_{7} \mathrm{C}_{3}$ [31]. To date, information about these transformations is mainly based on indirect observation, such as the similarity in the morphology and/or the chemical compositions of precipitates and sometimes the precipitation sites of these carbides [43]. This study, for the first time, provides direct evidence for the in-situ transformation of $\mathrm{M}_{2} \mathrm{C} \rightarrow \mathrm{M}_{6} \mathrm{C}$ and $\mathrm{M}_{7} \mathrm{C}_{3} \rightarrow \mathrm{M}_{6} \mathrm{C}$ (Figures 4-7). These observations strongly support the inferences of Baker and Nutting.

According to the SAED results of the $\mathrm{M}_{2} \mathrm{C}+\mathrm{M}_{6} \mathrm{C}$ complex precipitates, the $\mathrm{M}_{6} \mathrm{C}$ directly nucleated on the existing $\mathrm{M}_{2} \mathrm{C}$ and grew at the expense of $\mathrm{M}_{2} \mathrm{C}$. The amount of $\mathrm{M}_{2} \mathrm{C}$ precipitate was limited and could not be detected by $\mathrm{X}$-ray diffraction. It could be inferred that the $\mathrm{M}_{2} \mathrm{C}$ becomes exhausted at the equilibrium state. Based on these findings, the sequence of the carbide precipitation can be inferred as follows:

$$
\mathrm{MC}+\mathrm{M}_{7} \mathrm{C}_{3}+\mathrm{M}_{2} \mathrm{C} \rightarrow \mathrm{MC}+\mathrm{M}_{2} \mathrm{C}+\mathrm{M}_{7} \mathrm{C}_{3}+\mathrm{M}_{6} \mathrm{C} \rightarrow \mathrm{MC}+\mathrm{M}_{7} \mathrm{C}_{3}+\mathrm{M}_{6} \mathrm{C} .
$$

A very clear clue in the precipitation sequence of these types of carbides is that with prolonged aging the atomic percentage of carbon in the precipitates decreases. This phenomenon indicates that the dissolved carbon element in the $\alpha$-Fe plays an important role in forming various carbides. At the first stage of precipitation, the dissolved carbon and the dissolved $\mathrm{Cr}$ and $\mathrm{V}$ are abundant, and the thermodynamic driving force for the evolution of $M C$ and $M_{7} C_{3}$ is strong. With continued aging, the dissolved carbon, $\mathrm{V}$, and $\mathrm{Cr}$ content decrease, and the dissolved Mo element becomes relatively high; then the thermodynamic driving force for the evolution of $\mathrm{M}_{6} \mathrm{C}$ is stronger, and $\mathrm{M}_{6} \mathrm{C}$, with a low atomic 
percentage of carbon, turns out to be an equilibrium phase in the investigated steel. The discussion above clearly demonstrates that the localized $\mathrm{V}, \mathrm{Mo}, \mathrm{Cr}$, and especially the carbon content in the matrix exert a decisive role in the evolution of different types of carbides. The types of equilibrium precipitates determined in the present investigation are in good agreement with the equilibrium carbides that were thermodynamically calculated by Vyrostkova and Kroupa et al. [22,33,40].

\subsection{The Nucleation of the $M_{6}$ C Carbides}

It is well known that $\mathrm{M}_{6} \mathrm{C}$ is a Mo rich carbide and has a face-centered cubic structure. Baker and Nutting postulated in their work that $M_{6} C$ nucleated at the interface between $V_{4} C_{3}$ and ferrite matrix [14], while Kuo and Jia found that the nucleation of $\mathrm{M}_{6} \mathrm{C}$ frequently occurred on $\mathrm{M}_{23} \mathrm{C}_{6}$ when they studied the precipitation of a low alloy $\mathrm{Cr}-\mathrm{Mo}-\mathrm{V}$ steel [30]. From Figure 6e, it can be confirmed by the EDS line scan that the up part of the carbide in the white color in the DF image is $\mathrm{M}_{6} \mathrm{C}$. As shown in Figure 6b, the two white points that were represented by ' $A$ ' and ' $B$ ' can be easily recognized as $\mathrm{M}_{6} \mathrm{C}$ in the DF image (in this image, the $\mathrm{M}_{6} \mathrm{C}$ is bright and $\mathrm{M}_{7} \mathrm{C}_{3}$ is dark). They look like freshly nucleated carbides from their small sizes. Accordingly, this indicates that the $\mathrm{M}_{6} \mathrm{C}$ can nucleate at the interface of the existing $\mathrm{M}_{7} \mathrm{C}_{3}$ and the ferrite matrix in the aged low alloy $\mathrm{Cr}-\mathrm{Mo}-\mathrm{V}$ steel. Therefore, it can be concluded that the nucleation mechanism of $\mathrm{M}_{6} \mathrm{C}$ will change with the change of chemical compositions and aging conditions.

\subsection{The Planar Mismatch between Different Phases in the Complex Precipitates}

Based on the crystallographic relationships of the transformed complex carbides obtained so far in the specimen aged at $650{ }^{\circ} \mathrm{C}$ for $13,000 \mathrm{~h}$, together with the inter-planar spacing of the precipitates, the lattice misfits between the phases $\left(M_{2} C\right.$ and $M_{6} C, M_{7} C_{3}$ and $\left.M_{6} C\right)$ were calculated. The results are summarized in Table 6 . It can be seen that the lattice misfit between $\mathrm{M}_{2} \mathrm{C}$ and $\mathrm{M}_{6} \mathrm{C}$ is $-1.44 \%$ and that between $\mathrm{M}_{7} \mathrm{C}_{3}$ and $\mathrm{M}_{6} \mathrm{C}$ was $0.83 \%$. These small lattice misfits indicate that the interface between the complex precipitates was coherent even when the specimen was aged for $13,000 \mathrm{~h}$ at $650{ }^{\circ} \mathrm{C}$. For the specimen aged 30,000 h, however, no coherent interface between the different phases of the complex precipitates was observed. The results proposed the complex precipitates lost coherency during the aging period from $13,000 \mathrm{~h}$ to $30,000 \mathrm{~h}$ at $650{ }^{\circ} \mathrm{C}$. The exerted strain would be released by the loss of the coherency between different phases. Miyata and Sawaragi demonstrated in their work that if the precipitates lost coherency, the positive effect of the precipitates on improving creep properties would be reduced [34]. From this point of view, it can be inferred that the creep property and toughness of the specimen aged for $30,000 \mathrm{~h}$ in this work will be worse than the one aged for 13,000 $\mathrm{h}$.

Table 6. Lattice misfits between different phases of the transformed complex precipitates of the specimen aged at $650{ }^{\circ} \mathrm{C}$ for $13,000 \mathrm{~h}$.

\begin{tabular}{cccccc}
\hline Face & (hkil) carbide & $\begin{array}{c}\text { Lattice Spacing, } \\
\mathbf{d}_{\mathbf{1}}, \mathbf{n m}\end{array}$ & $\mathbf{( h k l )}_{\text {carbide }}$ & $\begin{array}{c}\text { Lattice Spacing, } \\
\mathbf{d}_{\mathbf{2}}, \mathbf{n m}\end{array}$ & $\begin{array}{c}\text { Lattice Misfits, } \\
\left(\mathbf{d}_{\mathbf{1}}-\mathbf{d}_{\mathbf{2}}\right) / \mathbf{d}_{\mathbf{1}}\end{array}$ \\
\hline$(41 \overline{1} 1)_{M_{7} C_{3}} / /(\overline{4} 2 \overline{2})_{M_{6} C}$ & $(41 \overline{51})_{M_{7} C_{3}}$ & 0.2281 & $(\overline{4} 2 \overline{2})_{M_{6} C}$ & 0.2262 & $0.83 \%$ \\
$(02 \overline{2} 1)_{M_{2} C} / /(266)_{M_{6} C}$ & $(02 \overline{2} 1)_{M_{2} C}$ & $2 \times 0.1253$ & $(266)_{M_{6} C}$ & 0.2542 & $-1.44 \%$ \\
\hline
\end{tabular}

\section{Conclusions}

The current work investigated the complex precipitates in a low alloy $\mathrm{Cr}-\mathrm{Mo}-\mathrm{V}$ steel under extreme long-term aging periods at $650{ }^{\circ} \mathrm{C}$ by combined X-ray diffraction and TEM characterization. The precipitation sequences and their crystallographic orientation relationships were established and compared to previous research findings. The main results can be summarized as follows: 
1. A near-equilibrium state of the low alloy $\mathrm{Cr}-\mathrm{Mo}-\mathrm{V}$ steel was achieved by aging at $650{ }^{\circ} \mathrm{C}$ for up to 30,000 h. The transformation of $M_{2} C$ to $M_{6} C$ and $M_{7} C_{3}$ to $M_{6} C$ were observed and confirmed by means of SAED and EDS line scan. Four types of precipitates, including $M C, M_{7} C_{3}, M_{6} C$, and $\mathrm{M}_{2} \mathrm{C}$, were found in the specimens in the near-equilibrium state.

2. The crystallographic orientation relationships between the in-situ transformed phases of the specimen aged for $13,000 \mathrm{~h}$ at $650{ }^{\circ} \mathrm{C}$ were established as follows:

$$
\begin{aligned}
& (41 \overline{51})_{M_{7} C_{3}} / /(\overline{4} 2 \overline{2})_{M_{6} C^{\prime}}[\overline{1} 2 \overline{1} 3]_{M_{7} C_{3}} / /[011]_{M_{6} C} \\
& (02 \overline{2} 1)_{M_{2} C} / /(266)_{M_{6} C^{\prime}}[11 \overline{26}]_{M_{2} C} / /[31 \overline{2}]_{M_{6} C}
\end{aligned}
$$

3. The crystallographic orientation relationships between the in-situ transformed phases of the specimen aged for $30,000 \mathrm{~h}$ at $650{ }^{\circ} \mathrm{C}$ were identified as:

$$
[\overline{6} 515]_{M_{7} C_{3}} / /[011]_{M_{6} C} \text { and }[\overline{1} 2 \overline{1} 0]_{M_{2} C} / /[5 \overline{6} 5]_{M_{6} C}
$$

4. The carbide precipitate sequence in the investigated $\mathrm{Cr}-\mathrm{Mo}-\mathrm{V}$ steel aged at $650{ }^{\circ} \mathrm{C}$ for $30,000 \mathrm{~h}$ was found to be: $\mathrm{MC}+\mathrm{M}_{7} \mathrm{C}_{3}+\mathrm{M}_{2} \mathrm{C} \rightarrow \mathrm{MC}+\mathrm{M}_{2} \mathrm{C}+\mathrm{M}_{7} \mathrm{C}_{3}+\mathrm{M}_{6} \mathrm{C} \rightarrow \mathrm{MC}+\mathrm{M}_{7} \mathrm{C}_{3}+\mathrm{M}_{6} \mathrm{C}$, which is consistent with the equilibrium calculations.

5. The direct evidence from TEM characterization revealed that the $\mathrm{M}_{6} \mathrm{C}$ nucleated at the interfaces of the existing $\mathrm{M}_{7} \mathrm{C}_{3}$ carbides.

6. The coherent interfaces between the in-situ transformed complex carbide precipitates became incoherent at prolonged aging time of 30,000 h.

Author Contributions: Conceptualization, Z.L. and C.L.; Investigation, Z.L. and L.M.; Methodology, H.Z.; Formal analysis, X.G. and J.D.; Writing-original draft preparation, Z.L.; Writing-review and editing, Z.L., H.Z., and X.G.; Visualization, L.M. and J.D.; Supervision, C.L.; Project administration, Z.L., J.D., and C.L.

Funding: This work was financially supported by the new product research program (X18ECQ0A00) of Baoshan Iron and Steel Co., Ltd.

Acknowledgments: Special thanks are expressed to Jiaqiang Gao for conducting the TEM and SAED experiment and to Xiaochuan Mi for the XRD analysis. Helpful discussions from Wei Wang is appreciated.

Conflicts of Interest: The authors declare no conflict of interest.

\section{References}

1. Bhadeshia, H.K.D.H. Design of Ferritic Creep-resistant Steels. ISIJ Int. 2001, 41, 626-640. [CrossRef]

2. Mitchell, D.R.G.; Ball, C.J. A quantitative X-ray diffraction and analytical electron microscopy study of service-exposed 2.25Cr-1Mo steels. Mater. Charact. 2001, 47, 17-26. [CrossRef]

3. Wang, Y.; Cheng, G.; Qin, M.; Li, Q.; Zhang, Z.; Chen, K.; Li, Y.; Hu, H.; Wu, W.; Zhang, J. Effect of high temperature deformation on the microstructure, mechanical properties and hydrogen embrittlement of 2.25Cr-1Mo-0.25 V steel. Int. J. Hydrogen Energy 2017, 42, 24549-24559. [CrossRef]

4. Pereira, P.A.S.; Franco, C.S.G.; Guerra Filho, J.L.M.; Dos Santos, D.S. Hydrogen effects on the microstructure of a 2.25Cr-1Mo-0.25 V steel welded joint. Int. J. Hydrogen Energy 2015, 40, 17136-17143. [CrossRef]

5. Chen, J.B.; Liu, H.B.; Pan, Z.Y.; Shi, K.; Zhang, H.Q.; Li, J.F. Carbide evolution and service life of simulated post weld heat treated 2.25Cr-1Mo steel. Mater. Sci. Eng. A 2015, 622, 153-159. [CrossRef]

6. Taneike, M.; Abe, F.; Sawada, K. Creep-strengthening of steel at high temperatures using nano-sized carbonitride dispersions. Nature 2003, 424, 294-296. [CrossRef] [PubMed]

7. Yu, X.; Babu, S.S.; Terasaki, H.; Komizo, Y.; Yamamoto, Y.; Santella, M.L. Correlation of precipitate stability to increased creep resistance of Cr-Mo steel welds. Acta Mater. 2013, 61, 2194-2206. [CrossRef]

8. Nguyen, T.D.; Sawada, K.; Kushima, H.; Tabuchi, M.; Kimura, K. Change of precipitate free zone during long-term creep in 2.25Cr-1Mo steel. Mater. Sci. Eng. A 2014, 591, 130-135. [CrossRef] 
9. Dépinoy, S.; Toffolon- Masclet, C.; Urvoy, S.; Roubaud, J.; Marini, B.; Roch, F.; Kozeschnick, E.; Gourgues, A.F. Carbide precipitation in 2.25 Cr-1 Mo bainitic steel: Effect of heating and isothermal tempering conditions. Metall. Mater. Trans. A 2017, 48, 2164-2178. [CrossRef]

10. Zhang, Y.; Luo, P.; Yan, H.; Zhang, H.; Li, J. The Effect of Bainite Type on the Evolution of Carbide Constituent During an Accelerated Aging in Cr-Mo-V Steel. J. Mater. Eng. Perform 2018, 28, 578-585. [CrossRef]

11. Wang, X.; Li, Y.; Li, H.; Lin, S.; Ren, Y. Effect of long-term aging on the microstructure and mechanical properties of T23 steel weld metal without post-weld heat treatment. J. Mater. Process Tech. 2018, 252, 618-627. [CrossRef]

12. Jiang, Z.; Wang, P.; Li, D.; Li, Y. Influence of the decomposition behavior of retained austenite during tempering on the mechanical properties of 2.25Cr-1Mo-0.25V steel. Mater. Sci. Eng. A 2019, 742, 540-552. [CrossRef]

13. Zieliński, A.; Golański, G.; Sroka, M. Influence of long-term ageing on the microstructure and mechanical properties of T24 steel. Mater. Sci. Eng. A 2017, 682, 664-672. [CrossRef]

14. Baker, R.G.; Nutting, J. The tempering of a Cr-Mo-V-W and a Mo-V steel. Iron and Steel Inst. Spec. Rep. 1959, 64, 1-22.

15. Janovec, J.; Vyrostkova, A. Effect of tempering on development of carbide particles in 2.7Cr-0.6Mo-0.3V steel. J. Mater. Sci. 1992, 27, 6564-6572. [CrossRef]

16. Ishiguro, T.; Ohnishi, K.; Watanabe, J. Effects of chromium and vanadium on the hydrogen attack susceptibility of boron added Cr-Mo steels. Tetsu-to-Hagane 1986, 72, 70-77. [CrossRef]

17. Vodarek, V.; Strang, A. Effect of nickel on the precipitation processes in $12 \mathrm{CrMoV}$ steels during creep at $550{ }^{\circ} \mathrm{C}$. Scripta Mater. 1997, 38, 101-106. [CrossRef]

18. Jiang, Z.H.; Wang, P.; Li, D.Z.; Li, Y.Y. The evolution of microstructure and mechanical properties of 2.25Cr-1Mo-0.25V steel with different initial microstructures during tempering. Mater. Sci. Eng. A 2017, 699, 165-175. [CrossRef]

19. Zhang, Y.; Miao, L.; Wang, X.; Zhang, H.; Li, J. Evolution behavior of carbides in 2.25Cr-1Mo-0.25V steel. Mater. Trans. 2009, 50, 2507-2511.

20. Wen, T.; Hu, X.F.; Song, Y.Y.; Yan, D.S.; Rong, L.J. Carbides and mechanical properties in a Fe-Cr-Ni-Mo high strength steel with different V contents. Mater. Sci. Eng. A 2013, 588, 201-207. [CrossRef]

21. Seung, P.H.; Seong, I.K.; Tae, Y.A.; Soon, T.H.; Young, W.K. Effects of extended heat treatment on carbide evolution in Cr-Mo steels. Mater. Charact. 2016, 115, 8-13.

22. Vyrostkova, A.; Kroupa, A.; Janovec, J.; Svoboda, M. Carbide reactions and phase equilibria in low alloy Cr-Mo-V steels tempered at 773-993 K. Part I: Experimental measurements. Acta Mater. 1998, 46, 31-38. [CrossRef]

23. Yu, J. Carbide stability diagrams in 2.25Cr-1Mo Steels. Metall. Trans. A 1989, 20, 1561-1564. [CrossRef]

24. Senior, B.A. A critical review of precipitation behaviour in $1 \mathrm{Cr}-\mathrm{Mo}-\mathrm{V}$ rotor steels. Mater. Sci. Eng. A 1988, 103, 263-271. [CrossRef]

25. Pitsch, W. The orientation relationship between cementite and ferrite in pearlite. Acta Metall. 1962, 10, 79-80. [CrossRef]

26. Heikkinen, V.K.; Hakkarainen, T.J. Precipitation associated with the climb of a $<100>$ dislocations in a low-carbon iron-vanadium alloy. Philos. Mag. 1973, 28, 237-280. [CrossRef]

27. Rong, W.; Dunlop, G.L. The crystallography of secondary carbide precipitation in high speed steel. Acta Metall. 1984, 32, 1591-1599. [CrossRef]

28. Lee, T.; Oh, C.; Ryu, S.; Kim, J. Crystallography and morphology of carbides in a low-cycle fatigued 1Cr-1Mo-0.25V steel. Metall. Mater. Trans. A 2011, 42, 147-157. [CrossRef]

29. Dyson, D.J.; Andrews, K.W. Carbide $\mathrm{M}_{7} \mathrm{C}_{3}$ and its formation in alloy steels. J. Iron Steel Inst. 1969, 207, 208-219.

30. Kuo, K.H.; Jia, C.L. Crystallography of $\mathrm{M}_{23} \mathrm{C}_{6}$ and $\mathrm{M}_{6} \mathrm{C}$ precipitated in a low alloy steel. Acta Mater. 1985, 33, 991-996. [CrossRef]

31. Baker, R.G.; Nutting, J. The tempering of 2.25Cr-1Mo steel after quenching and normalizing. J. Iron Steel Inst. 1959, 192, 257-268.

32. Woodhead, J.H.; Quarrell, A.G. Role of carbides in low-alloy creep resisting steels. J. Iron Steel Inst. 1965, 203, $605-620$. 
33. Kroupa; Havránková, J.; Svoboda, M.; Coufalová, M.; Vřešt'Ál, J. Phase diagram in the iron-rich corner of the Fe-Cr-Mo-V-C system below 1000 K. J. Phase Equ. 2001, 22, 312-323. [CrossRef]

34. Miyata, K.; Sawaragi, Y. Effect of Mo and W on the phase stability of precipitates in low Cr heat resistant steels. ISIJ Int. 2001, 41, 281-289. [CrossRef]

35. Bhadeshia, H.K.D.H.; Christian, J.W. Bainite in steels. Metall. Trans. A 1990, 21, 767-797. [CrossRef]

36. Rempel, A.A. Atomic and vacancy ordering in nonstoichiometric carbides. Physics-Uspekhi 1996, 39, 31-56. [CrossRef]

37. Andrews, K.W.; Dyson, D.J.; Keown, S.R. Interpretation of Electron Diffraction Pattern, 1st ed.; Hilger \& Watts Ltd.: London, UK, 1967; p. 173.

38. Morniroli, J.P.; Bauer-Grosse, E.; Gantois, M. Crystalline defect in $\mathrm{M}_{7} \mathrm{C}_{3}$ carbide. Phil. Mag. A 1983, 48, 311-327. [CrossRef]

39. Zhang, Y.T.; Han, H.B.; Miao, L.D.; Zhang, H.Q.; Li, J.F. Quantitative carbide analysis using the Rietveld method for 2.25Cr-1Mo-0.25V steel. Mater. Charact. 2009, 60, 953-956.

40. Kroupa, A.; Vyrostkova, A.; Svoboda, M.; Janovec, J. Carbide reactions and phase equilibria in low alloy Cr-Mo-V steels tempered at 773-993 K. Part II: Theoretical calculations. Acta Mater. 1998, 46, 39-49. [CrossRef]

41. Fu, R.D.; Wang, T.S.; Zhou, W.H. Characterization of precipitates in a 2.25Cr-1Mo-0.25V steel for large-scale cast-forged products. Mater. Charact. 2007, 58, 968-973. [CrossRef]

42. Andrews, K.W.; Hughes, H.; Dyson, D.J. Constitution diagrams for Cr-Mo-V steels. J. Iron Steel Inst. 1972, 210, 337-350.

43. Inoue, A.; Masumoto, T. Carbide reactions (M3C $\rightarrow \mathrm{M} 7 \mathrm{C} 3 \rightarrow \mathrm{M} 23 \mathrm{C} 6 \rightarrow \mathrm{M} 6 \mathrm{C})$ during tempering of rapidly solidified high carbon Cr-W and Cr-Mo steels. Metall. Trans. A 1980, 11, 739-747. [CrossRef]

(C) 2019 by the authors. Licensee MDPI, Basel, Switzerland. This article is an open access article distributed under the terms and conditions of the Creative Commons Attribution (CC BY) license (http://creativecommons.org/licenses/by/4.0/). 